\title{
Precursors and outcome of customer satisfaction/delight in business-to-consumer relationships in Botswana
}

\begin{tabular}{|c|c|}
\hline \multicolumn{2}{|c|}{$\begin{array}{l}\text { Authors: } \\
\text { Olumide Jaiyeoba }{ }^{1} \text { (1) } \\
\text { Douglas T. Svotwa }{ }^{2} \text { (1) } \\
\text { Mornay Roberts-Lombard }{ }^{3}\end{array}$} \\
\hline \multicolumn{2}{|c|}{$\begin{array}{l}\text { Affiliations: } \\
{ }^{1} \text { Faculty of Business and } \\
\text { Accounting, Botho University, } \\
\text { Gaborone, Botswana }\end{array}$} \\
\hline \multicolumn{2}{|c|}{$\begin{array}{l}\text { ²Department of Business } \\
\text { Management, Botho } \\
\text { University, Gaborone, } \\
\text { Botswana }\end{array}$} \\
\hline \multicolumn{2}{|c|}{$\begin{array}{l}{ }^{3} \text { Department of Marketing } \\
\text { Management, School of } \\
\text { Consumer Intelligence and } \\
\text { Information Systems, College } \\
\text { of Business and Economics, } \\
\text { University of Johannesburg, } \\
\text { Johannesburg, South Africa }\end{array}$} \\
\hline \multicolumn{2}{|c|}{$\begin{array}{l}\text { Corresponding author: } \\
\text { Mornay Roberts-Lombard, } \\
\text { mornayrl@uj.ac.za }\end{array}$} \\
\hline $\begin{array}{l}\text { Dates: } \\
\text { Received: } 11 \\
\text { Accepted: } 17 \\
\text { Published: } 30\end{array}$ & $\begin{array}{l}\text { ct. } 2019 \\
\text { uly } 2020 \\
\text { Sept. } 2020\end{array}$ \\
\hline \multicolumn{2}{|c|}{$\begin{array}{l}\text { How to cite this article: } \\
\text { Jaiyeoba, O., Svotwa, D.T., \& } \\
\text { Roberts-Lombard, M. (2020). } \\
\text { Precursors and outcome of } \\
\text { customer satisfaction/delight } \\
\text { in business-to-consumer } \\
\text { relationships in Botswana. } \\
\text { South African Journal of } \\
\text { Business Management, } \\
\text { 51(1), a1809. https://doi. } \\
\text { org/10.4102/sajbm. } \\
\text { v51i1.1809 }\end{array}$} \\
\hline \multicolumn{2}{|c|}{$\begin{array}{l}\text { Copyright: } \\
\text { ( 2020. The Authors. } \\
\text { Licensee: AOSIS. This work } \\
\text { is licensed under the } \\
\text { Creative Commons } \\
\text { Attribution License. }\end{array}$} \\
\hline \multicolumn{2}{|l|}{ Read online: } \\
\hline 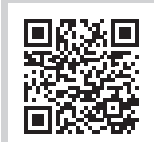 & $\begin{array}{l}\text { Scan this QR } \\
\text { code with your } \\
\text { smart phone or } \\
\text { mobile device } \\
\text { to read online. }\end{array}$ \\
\hline
\end{tabular}

\section{Authors:}

Affiliations:

${ }^{1}$ Faculty of Business and

Accounting, Botho University,

${ }^{2}$ Department of Business

Management, Botho

University, Gaborone,

Management, School of

Consumer Intelligence and University of Johannesburg Johannesburg, South Africa

Mornay Roberts-Lombard,

mornayrl@uj.ac.za

Dates:

Published: 30 Sept. 2020

How to cite this article:

oba, O., Svotwa, D.T., \&

Precursors and outcome of

customer satisfaction/delight

South African Journal of

ness Management,

org/10.4102/sajbm.

v51i1.1809

Copyright:

Licensee: AOSIS. This work

is licensed under the

Creative Commons

Attribution License.
Customers in emerging African markets such as Botswana are becoming more willing to switch
brands. They have increased choice and can switch service providers easily, which is not beneficial

Customers in emerging African markets such as Botswana are becoming more willing to switch
brands. They have increased choice and can switch service providers easily, which is not beneficial

Purpose: This study examines the degree and the extent to which the satisfaction/delight of cellular network customers in Botswana is affected by the service delivery skills of network employees, the value received from offerings of the network and the trust that they have within a service environment. In addition, the effect of customer satisfaction/delight (CSD) on their loyalty is established.

Design/methodology/approach: The research design applied was descriptive, and selfadministered survey instruments were used to collect data from satisfied cellular network customers. For the data analysis, 350 completed questionnaires were used. In addition, the testing of proposed models was secured.

Findings/results: Perceived employee service delivery, perceived value and trust have a significant positive influence on the satisfaction/delight experiences of customers, while such experiences influence customer loyalty significantly and positively.

Practical implications: This study guides cellular providers towards establishing how service delivery, value and trust could improve customer satisfaction/delight among cellular customers in Botswana, leading to sustainable customer loyalty and a competitive advantage for the firm.

Originality/value: Few other studies have investigated CSD experiences in relation to the stated precursors and outcome in an emerging African market.

Keywords: perceived employee service delivery skills; perceive value; trust; customer satisfaction; customer delight; customer loyalty.

\section{Introduction}

Competition in the Botswana mobile telecommunications sector has been intense, arising from the proliferation of Internet users owing to lower Internet prices and easy international interconnectivity (Telegraph, 2015). Considering this increase in competition, service providers need to understand that the satisfaction of customers is no longer sufficient to secure customer loyalty (CL) (Meyer, Barnes, \& Friend, 2017). Currently, the telecommunications market in Botswana is one of the most liberated in the Sub-Saharan African region in terms of regulatory reforms (BuddyComm, 2019). The International Telecommunication Union describes the performance of the Botswana mobile communications market as the third best performer in Southern Africa after Mauritius and South Africa (BOCRA, 2018). There are currently three major cellular service providers competing actively in the mobile segment of the Botswana market, namely, Mascom Wireless, Orange and Botswana Telecommunications Corporation (BTCL). By March 2019, Macom secured 1702807 mobile customers, Orange had a total of 1146860 customers and BTCL served 503670 cellular customers in Botswana (BOCRA, 2019). Considering the high level of competitiveness between these cellular providers in Botswana, it becomes imperative that they understand factors that could influence customer satisfaction/ delight (CSD), which could ultimately lead to CL. Barnes, Collier, Howe and Hoffman (2016) state that customers want to be delighted to strengthen their commitment and ultimately their loyalty to the service provider. Such delight should flow from a positive emotional and pleasure experience that will motivate the customer to remain with the supplier, even if better offers are provided by competitors (Torres, Milman, \& Park, 2018). 
to the company as it loses spending power. In essence, customers in emerging African markets therefore need to be provided with positive levels of service quality, value for money and trust to secure their delight, and ultimately their loyalty in the long term.

Studies by Chang, Wang and Yang (2009), Soares and Proenca (2015) and Bolton et al. (2013) have investigated the relationship between satisfaction, trust, service experience perception and perceived value (PV) in both established and emerging markets. However, limited research has been done to establish the interrelationship of satisfaction/delight and its antecedents (perceived employee service delivery, PV and trust) and its outcome (CL) in a developing economy such as Botswana. Furthermore, in an African business context, customer delight is a new area of academic research which has received limited investigation as an interactive construct. In the context of this study, customer delight is viewed as a level higher than customer satisfaction, as contended by Roberts-Lombard and Petzer (2018).

Ball and Barnes (2017) argue that customers today are less likely to be loyal and require more than just satisfaction to secure a stronger commitment to the supplier. Therefore, a greater focus on delight is required through a positive engagement with employees, a positive service experience resulting in joy and an ultimate feeling of surprise that exceeds customer expectations. Through such an approach, a supplier can reduce the willingness of a customer to switch to a competitor, as the experience of delight strengthens commitment and ultimately loyalty (Kim, Vogt, \& Knutson, 2015). Considering this, the study intended to determine whether the perceptions of cellular network customers, their value received from the offerings of the provider and their trust in the cellular provider influence their customer delight experiences. Furthermore, the study also wanted to establish the extent to which their delight would have an influence on their future CL.

The theoretical contribution made by the study is through the explanation of the nomological web between perceived employee service delivery, PV, trust, CSD and CL in Botswana. This study expands on the model proposed by RobertsLombard and Petzer (2018), and attempts to substantiate the findings of this study in South Africa through an expanded model focus in a similar industry context. Therefore, this study makes a contribution that is complementary to earlier studies. In terms of the practical perspective, the study contributes by informing cellular providers on how the different independent variables can enhance customer delight/satisfaction, ultimately strengthening long-term CL and providing a competitive edge for cellular network providers.

The theories grounding the study are introduced next, the different formulated hypotheses are discussed and a model is proposed. This is followed by a discussion of the research methodology, the findings and contributions of the study and, finally, the recommendations.

\section{Literature review}

The theory of reasoned action (TRA) and the relationship market theory (RMT) underpin this study, mainly regarding the constructs under investigation and their perceived relationships. The major proponents of TRA, Ajzen and Fishbein (1980) state that consumer behavioural changes result from two main factors. Firstly, consumers hold certain beliefs about performing or not performing certain behaviours and the consequences involved; and secondly, consumers hold certain beliefs about whether people may or may not approve the performance of certain targeted behaviours (Hoogstraten, De Haan, \& Ter Horst, 1985).

In contrast, RMT postulates that firms need to develop valuable long-term relationships which are mutually beneficial to them and their customers through social interaction, as customers are willing to interact in relationship-building initiatives (O'Malley \& Tynan, 2000; Ravald \& Grönroos, 1996). This view is affirmed by Grönroos (2017a) and Kotler and Keller (2016) who posit that relationship marketing enables organisations to initiate and deliver consolidated customer service with the aid of effective individual account intelligence. Companies can provide market offerings, services and programmes which rely on the information that the firm possesses on each customer. Considering this, it can be argued that a positive association exists between relationship marketing and business performance in a Business-to-Consumer (B2C) environment (Grönroos, 2017a; Gummesson, 2017; Kuhn \& Mostert, 2018; Leverin \& Liljander, 2006; Zhang, Watson, Palmatier, \& Dant, 2016).

\section{A perspective on previous customer delight studies}

The current global competitive service environment requires an understanding of the changing nature of $\mathrm{B} 2 \mathrm{C}$ relationship building dynamics. Service providers can no longer secure the loyalty of its customer base by securing only satisfaction. Therefore, an increased understanding of customer delight and its relevance in the building of long-term customer relationships is required. There is increased evidence in the marketing theory that satisfaction only meets customer expectations, while customer delight ensures a positive surprise that is above the anticipations of the customer (Berman, 2005; Elias-Almeida, Miranda, \& Almeida, 2016; Torres, Fu \& Lehto, 2014). Customer delight is a field of study that has been primarily explored in established markets across the globe. Limited research studies have explored customer delight in a B2C environment in emerging markets, especially in Africa. Table 1 reflects on customer delight studies that were previously conducted worldwide.

Table 1 illustrates different research studies conducted on delight over the past three decades. However, no previous study investigated customer delight, its precursors and, ultimately, its ability to influence the loyalty of customers from a Botswana perspective. Considering this, there is a 
TABLE 1: Previous research studies conducted on delight in the world over the past three decades.

\begin{tabular}{|c|c|c|}
\hline Article title & Key premise & Article reference \\
\hline $\begin{array}{l}\text { The evolution of the customer delight construct: } \\
\text { Prior research, current measurement and } \\
\text { directions for future research }\end{array}$ & $\begin{array}{l}\text { To present research aims to summarise the literature on customer delight, identify trends and } \\
\text { debates, create an instrument to measure delight and propose directions for future research and } \\
\text { loyalty. }\end{array}$ & $\begin{array}{l}\text { Ronzoni and Torres } \\
\text { (2018) }\end{array}$ \\
\hline $\begin{array}{l}\text { Customer satisfaction/delight and behavioural } \\
\text { intentions of cell phone network customers - } \\
\text { An emerging market perspective }\end{array}$ & $\begin{array}{l}\text { To investigate the extent to which the satisfaction/delight experienced by customers of cell phone } \\
\text { network service providers is influenced by their perceptions of the networks' employee service } \\
\text { delivery skills and the value that the customers derive from the networks' offerings. In turn, the } \\
\text { influence of the extent of their satisfaction/delight on future behavioural intention (BI) is determined. }\end{array}$ & $\begin{array}{l}\text { Roberts-Lombard and } \\
\text { Petzer (2018) }\end{array}$ \\
\hline $\begin{array}{l}\text { Relationships amongst customer satisfaction, } \\
\text { delight and loyalty in the hospitality industry }\end{array}$ & $\begin{array}{l}\text { To understand how customer satisfaction and delight influence loyalty and to understand the } \\
\text { multiphase framework of loyalty, including cognitive, affective and conative loyalties. }\end{array}$ & Kim et al. (2015) \\
\hline $\begin{array}{l}\text { Customer delight: Universal remedy or a } \\
\text { double-edged sword? }\end{array}$ & $\begin{array}{l}\text { To investigate whether customer delight necessarily requires surprise and whether a misdirected } \\
\text { delight strategy can backfire by creating disloyal customers. }\end{array}$ & Ludwig et al. (2015) \\
\hline $\begin{array}{l}\text { Destination marketing and visitor experiences: } \\
\text { The development of a conceptual framework }\end{array}$ & To explore the relationship between destination image, visitor delight and place attachment. & $\begin{array}{l}\text { Jiang, Ramkissoon and } \\
\text { Mavondo (2016) }\end{array}$ \\
\hline $\begin{array}{l}\text { Are there gender differences in what drives } \\
\text { customer delight? }\end{array}$ & $\begin{array}{l}\text { Previous research in the area of customer delight has revealed some of the factors that define and } \\
\text { drive the customer delight experience. Despite the emerging literature on the subject, the question } \\
\text { remains: are guest from different cultures likely to be delighted by different things? }\end{array}$ & Torres et al. (2014) \\
\hline $\begin{array}{l}\text { From customer satisfaction to customer } \\
\text { delight - Creating a new standard of service } \\
\text { for the hotel } \\
\text { Industry }\end{array}$ & $\begin{array}{l}\text { To provide a typology of customer delight in the hotel industry. By doing so, it identifies patterns by } \\
\text { which hotels delight their guests. The article explores the Torres and Kline model in light of the data } \\
\text { and proposes an addition to the model. }\end{array}$ & $\begin{array}{l}\text { Torres and Kline } \\
\text { (2013) }\end{array}$ \\
\hline $\begin{array}{l}\text { To delight, or not to delight? This is the question } \\
\text { service firms must address }\end{array}$ & The relevance and need for customer delight is explored. & $\begin{array}{l}\text { Barnes, Beauchamp } \\
\text { and Webster (2010) }\end{array}$ \\
\hline $\begin{array}{l}\text { Customer delight in a retail context: } \\
\text { Investigating delightful and terrible shopping } \\
\text { experiences }\end{array}$ & $\begin{array}{l}\text { To examine customer delight in a retail-shopping context. Specifically, qualitative research was } \\
\text { conducted to determine the sources of delightful and terrible shopping experiences for retail } \\
\text { shoppers. }\end{array}$ & $\begin{array}{l}\text { Arnold, Reynolds, } \\
\text { Ponder and Lueg, } \\
\text { (2005) }\end{array}$ \\
\hline How to delight customers & The conceptual differences between satisfaction and delight are explored. & Berman (2005) \\
\hline $\begin{array}{l}\text { Customer delight, foundations, findings and } \\
\text { managerial insight }\end{array}$ & $\begin{array}{l}\text { To establish a behavioural basis towards customer delight, empirically testing its hypothesised } \\
\text { antecedents and consequences and exploring the resulting implications. }\end{array}$ & Oliver et al. (1997) \\
\hline
\end{tabular}

Note: Please see the full reference list of the article, Jaiyeoba, O., Svotwa, D.T., \& Roberts-Lombard, M. (2020). Precursors and outcome of customer satisfaction/delight in

business-to-consumer relationships in Botswana. South African Journal of Business Management 51(1), a1809. https://doi. org/10.4102/sajbm.v51i1.1809, for more information.

clear need for research to investigate these relationships from an emerging African market perspective, thereby contributing to current, theoretical thought around delight, its precursors and influence on outcomes such as loyalty.

\section{Proposed model development}

\section{Interrelationship of perceived employee service delivery skills and customer satisfaction/delight experiences}

Multiple researchers in both the telecommunications and banking sectors have confirmed a positive relationship between employee service delivery skills and CSD. Dickson, McVittie and Kapilashrami (2017), Verma, Sharma and Sheth (2016) and Loke, Taiwo, Salim and Downe (2011) found that competent and knowledgeable employees enhanced customer satisfaction, while Zafar, Zafar, Asif, Hunjra and Ahmad (2012) experienced conflict handling in the banking sector to be a key attribute that correlates with customer satisfaction. The above findings are corroborated by Moghavvemi, Lee and Lee (2018), who argued that the expertise of the employee, which encompasses intellectual, technical, commercial and interpersonal skills, is valued most by bank customers, thus positively contributing to customer satisfaction. Similar research studies conducted by Torres et al. (2018) revealed that customer delight values of quality and effective customer service may enhance customer satisfaction and loyalty. Customer delight is a relatively novel construct and has generally received little attention as a relational determinant more specifically in emerging economies as contended by Roberts-Lombard and Petzer (2018) and Bowden-Everson, Dagger and Elliot (2013). Hence, the following hypothesis is proposed:

H1: PESDs influence the CSD experiences of cell phone network service provider customers.

\section{Interrelationship of perceived value and customer satisfaction/delight experiences}

The PV of a product or service is normally defined from the perspective of the customer because he/she is the one who is involved in the consumption of the product or service (Jiang, Jun, \& Yang, 2016). The PV depends on the personal characteristics of the consumer, such as service knowledge and the place where the service is offered (Chuah, Marimuthu, Kandampully, \& Bilgihan, 2017; Cossío-Silva, RevillaCamacho, Vega-Vázquez, \& Palacios-Florencio, 2016; LeroiWerelds, Streukens, Brady, \& Swinnen, 2014; Nyadzayo \& Khajehzadeh, 2016). Petrick (2004) devised a model by which he found that PV had a great influence on repeat visits and ultimately customer satisfaction, especially for first-time cruise travellers. In a related study conducted by Jin, Lee and Lee (2015) on 376 customers in South Korean water parks, the findings revealed that customers' satisfaction is derived from positive experience quality and PV. In other words, in situations where customers benefit in terms of the PV of the service, they are likely to be satisfied. These findings are corroborated by Galvão, De Carvalho, De Oliveira and De Medeiros (2018), De Waal \& Van der Heijden (2016) and Maria Correia Loureiro, Miranda and Breazeale (2014), who postulated that PV is related to customer satisfaction. Ronzoni and Torres (2018) posit that despite the decades long study of customer satisfaction only it has been suggested that measuring satisfaction is not sufficient to define and assess customer experience. Based on the aforementioned, this study not only investigated the myriad of relationship between PESD, PV, trust and customer satisfaction, but also incorporated customer delight to find out to what extent do they have implications on CL in the cellular phone industry in Botswana. Therefore, the following hypothesis is proposed: 
H2: PV influences the CSD experiences of cell phone network service provider customers.

\section{Interrelationship of trust and customer satisfaction/delight experiences}

Scholars such as Park, Kim and Kwon (2017), Melewar, Foroudi, Gupta, Kitchen and Foroudi (2017), Elbeltagi and Agag (2016), and Rousseau, Sitkin, Burt and Camerer (1998) describe trust as a state of mind where there is an open acceptance towards positive behavioural intentions amongst parties. Previous research studies by Elbeltagi and Agag (2016), Giovanis, Athanasopoulou, and Tsoukatos, 2015, Dabholkar and Sheng (2012), Yoon and Kim (2000), and Crosby, Evans and Cowles (1990) have established a correlation between trust and satisfaction that is positive. This view is further supported by Izogo (2016) and Leninkumar (2017), who posited the existence of a relationship between customer satisfaction and trust that is positive. In contrast, some researchers have indicated that trust precedes customer satisfaction (Chang, 2014; Ercis, Unal, Candan, \& Yildirim, 2012; Gul, 2014) and contended that customers initially trust service providers on the basis of specific factors leading to customer satisfaction. This study presupposes that customer satisfaction is the major predictor of trust, in that customers need to be satisfied initially with the services they get from cell phone providers before trusting them. Ronzoni and Torres(2018) concluded by stating that despite the emergence of customer delight over the past 20 years, there are several different definitions and conceptualisation of the customer delight phenomenon. They thus stated that there is a need for clearer conceptualisation, resolution of outstanding debates or controversies and the establishment of consistent measures to quantify its occurrence. Based on the various research findings, the following hypothesis is proposed:

H3: Trust influences the CSD experiences of cell phone network service provider customers.

\section{Interrelationship of customer satisfaction/delight experiences and loyalty}

Subhashini and Preetha (2018) defined customer satisfaction as the 'customer's fulfilment response to a consumption experience or some part of it'. Customer delight, on the contrary, as defined by Berman (2005) and supported by Torres et al. (2018), Preko, Agbanu and Feglo (2014), and Torres and Kline (2013), results from going beyond satisfaction and delivering the best pleasurable experience for the customer, and delighted customers normally have an extraordinary service experience (Kao, Tsaur, \& Wu, 2016). Ronzoni and Torres (2018) and Torres and Kline (2013) further argued that customer delight not only became known by many as a construct grounded on customer effect and human needs satisfaction, but also demonstrated the highest state of engagement experienced by customers in the context of hedonic and utilitarian fulfilment.

Research has confirmed a relationship between customer satisfaction and loyalty that is perceived as positive, as attested by Saeed and Siddiqui (2016), Bowen and McCain (2015), Chiou and Droge (2006), Gerpott, Rams and Schindler (2001). Ofori, Boakye and Narteh (2018) further postulated that satisfied customers in most instances repurchased the supplier's products and services, resulting in CL and increased firm profitability. In support of the above assertions, studies such as those by Consuegra, Molina and Esteban (2007), Wong and Zhou (2006) and Leninkumar (2017) also posited that the more satisfied customers are with the service of their cell phone providers, the more loyal they are likely to be to them. Krystallis and Chrysochou (2014) and Nyadzayo and Khajehzadeh (2016) also held that customer satisfaction, as a post-purchase consequence regarding a particular service provider or brand, is a core element of CL. The literature further affirms the existence of a positive relationship between customer satisfaction and loyalty, as confirmed by Xu, Peak and Prybutok (2015) and Zhang, Huang, He and Wang (2015). Ronzoni and Ronzoni (2018) further noted that customer delight represents a higher state of emotional arousal/excitement than customer satisfaction. They thus posit that satisfaction is based on the disconfirmation paradigm by stating that the cognitive evaluation of satisfaction is likened to attitude, while affect resonates with customer delight. Hence, the need to explicate the nomological web between PESDs, PV, TRST, CSD and CL in Botswana as the country seeks to improve and consolidate its competitiveness in the cellular phone industry. Therefore, the following hypothesis is proposed:

H4: CSD experiences influence the loyalty of cell phone network service provider customers.

Given the various constructs and formulated hypotheses provided, Figure 1 gives an illustration of the theoretical model proposed for this study.

\section{Methodology}

An explanatory research design was used in this empirical study as advocated by Saunders and Lewis (2012), and data received from customers in possession of a cell phone, who had an indication of the service provider to patronise, and perceived themselves as satisfied customers during the period that the survey was conducted. These customers represent the sampling dynamics of the study. The study included customers who were satisfied with their service provider in Botswana. The study is built on an extended model based on the original model proposed by RobertsLombard and Petzer (2018). The extended model is applied

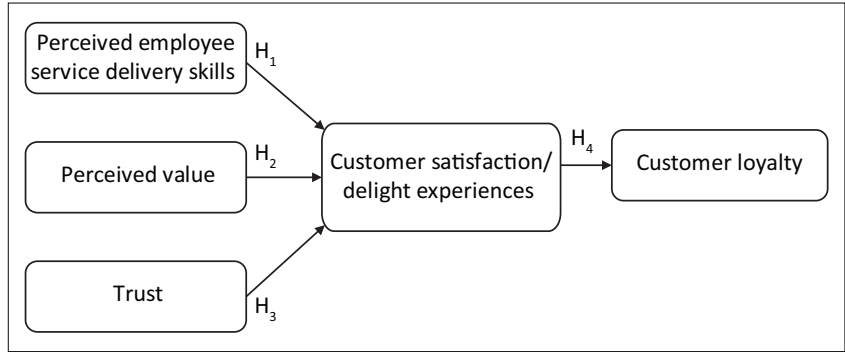

FIGURE 1: Proposed conceptual model. 
to the cellular industry of Botswana to explore CSD experiences of customers in this emerging African market.

Screening deliberations were adopted to establish that targeted respondents met the necessary conditions to be involved in the empirical study. Furthermore, respondents across cell phone network service providers, who had an indication of which network to use and regarded themselves as satisfied customers of their network, were involved in the study. Research assistants in Gaborone were used to get data from respondents. They were also requested to use nonprobability sampling by meeting predetermined age and gender quotas in a purposeful manner to make sure that the target population was well represented. Self-administered questionnaires were distributed to respondents who were patronising cell phone network service providers, had a choice in the network used and regarded themselves as satisfied customers. Respondents completed the questionnaires and returned them to the fieldworkers. Data were collected over a 4-week period, and a total of 350 useable questionnaires was analysed.

According to Zikmund (2000), the self-administered questionnaire plays an important role in management research with respect to data collection. Bush and Hair (1985) lend credence to the assertion espoused above with regard to the basic features of the technique. Responses to the scale items in this study were subjected to a seven-point Likert scale. Apart from demographic metrics, the study constructs were evaluated using scales adapted from the extant literature as follows: from Van Vuuren (2011) for PESDs) and for TRST, from Nyadzayo (2010) for PV, from Berman (2005) for CSD and from Dagger and Sweeney (2007) for CL.

This study used SPSS for descriptive statistics to elucidate the telescopic view of the demographic metric of the sampled audience, and 22 scale items evaluating the five constructs of the study. Confirmatory factor analysis (CFA) was conducted using maximum likelihood for extraction and varimax rotation to explicate the nomological web of myriad of items of the constructs. The measurement model and structural model were tested using SPSS Amosversion 23 (2015). Before the structural model was measured, subliminal assumptions of covariance-based structural equation modelling (SEM) using Amos 23.0 were addressed, as well as issues of linearity and multicollinearity (Gaskin, 2013).

\section{Empirical findings Profile of respondents}

Respondents' ages ranged between 18 and 35. A total of $22 \%$ of the sampled respondents contended that they were satisfied with their major choice of cell phone network service provider, while $78 \%$ noted that they were satisfied with their primary service provider. In terms of gender, $39.4 \%$ of the respondents were male and $60.6 \%$ female. In addition, $44.8 \%$ of the respondents used Mascom, 33\% used Be-mobile and 22.2\% used Orange as their major cell phone network service provider. Finally, $42.2 \%$ of the targeted samples were contract customers, while $57.8 \%$ were prepaid.

\section{Measurement model assessment}

Amos 23.0 was used to conduct CFA which was implemented on 22 scale items to elucidate psychometric nomenclature of five-construct model (Table 2). Furthermore, the model was specified and adjusted on the basis of modification indices calculated to explicate the model fit as postulated by Jöreskog and Sörbom (1993). The goodness-of-fit metrics are within the established threshold as postulated by Hair, Black, Babin and Anderson (2014). The goodness of model fit is all above the threshold of 0.9 , and the root mean square error of approximation (RMSEA) is below a value of 0.08 as indicated in the extant literature. Furthermore, the myriad of the goodness-of-fit metrics elucidates good model fit (Hair et al., 2014).

The factor loadings, the variances explained and the means and standard deviations of 22 items used to measure the five constructs of the study were also determined (Table 3). The factor loading for each of the 22 items is above 0.5 and ranges from 0.501 to 0.992 . The explained variance of each item is above 0.3 and ranges from 0.441 to 0.958 . The means vary from 2.76 to 4.48 , with standard deviations from 1.16 to 2.49 . The regularity of the myriad of items measuring the constructs of the study was elucidated.

\section{Convergent validity, discriminant validity and composite trait reliability}

The convergent validity, discriminant validity and composite trait reliability of the constructs were also determined (Table 4). Convergent validity was evaluated by establishing whether the average variance extracted (AVE) for each construct is above 0.5 (Hair et al., 2014). It is evident that the AVEs for all five constructs exceed 0.5 and range from 0.610 to 0.968 , which elicit convergent validity. Discriminant validity was evaluated by determining whether the AVEs of the constructs exceed the interconstruct correlations. The AVE values vary from 0.243 to 0.556 , well below the lowest variance extracted (61.0\%). Discriminant validity can therefore be established. Furthermore, composite trait reliability was evaluated by

TABLE 2: Measures for goodness-of-fit (measurement model).

\begin{tabular}{lccccccccccc}
\hline CMIN & $d \boldsymbol{f}$ & $\boldsymbol{p}$ & CMIN/df & NFI & RFI & IFI & TLI & CFI & RMSEA \\
\hline 345.33 & 125 & 0.00 & 2.762 & 0.98 & 0.91 & 0.96 & 0.97 & 0.94 & 0.042 \\
\hline
\end{tabular}

CMIN, contrast media-induced nephropathy; $d f$, degree of freedom; RFI, relative fit index; IFI, incremental fit index; TLI, Tucker Lewis index; CFI, comparative fit index; RMSEA, root mean square error of approximation. 
determining if the threshold value of 0.7 was exceeded. Based on the aforementioned, the composite trait reliabilities exceed the threshold value of 0.7, ranging from 0.693 to 0.986 . Composite trait reliability could therefore be established.

\section{Linearity and multicollinearity}

Linear relationships exist between the myriad of constructs in the structural model (PESDs and CSD, PV and CSD, trust and $C S D, C S D$ and $C L$ ) as the $F$-values for the respective linear models are above $F$-values of other models considered (Gaskin, 2013). Multicollinearity assumptions were also not violated as tolerance values are less than 1 and variance inflation factors (VIFs) are greater than 1 as postulated in the extant literature (Gaskin, 2013).

TABLE 3: Factor loadings, variance explained, means $(M)$ and standard deviations (SDs).

\begin{tabular}{|c|c|c|c|c|c|}
\hline Construct & Item & Factor loading & Variance explained & $M$ & SD \\
\hline \multirow[t]{4}{*}{ PESDs } & $\mathrm{X}_{1}$ & 0.529 & 0.480 & 3.79 & 2.21 \\
\hline & $x_{2}$ & 0.766 & 0.586 & 4.41 & 2.49 \\
\hline & $\mathrm{X}_{3}$ & 0.922 & 0.849 & 2.86 & 1.62 \\
\hline & $x_{4}$ & 0.951 & 0.904 & 3.36 & 2.12 \\
\hline \multirow[t]{5}{*}{ PV } & $x_{5}$ & 0.502 & 0.441 & 3.05 & 1.64 \\
\hline & $x_{6}$ & 0.863 & 0.746 & 2.76 & 1.69 \\
\hline & $x_{7}$ & 0.817 & 0.668 & 4.20 & 2.08 \\
\hline & $\mathrm{X}_{8}$ & 0.795 & 0.633 & 3.36 & 1.80 \\
\hline & $X_{9}$ & 0.874 & 0.764 & 3.88 & 2.18 \\
\hline \multirow[t]{3}{*}{ TRST } & $\mathrm{X}_{10}$ & 0.728 & 0.531 & 3.75 & 1.23 \\
\hline & $x_{11}$ & 0.742 & 0.551 & 3.95 & 2.24 \\
\hline & $\mathrm{X}_{12}$ & 0.911 & 0.830 & 3.48 & 1.99 \\
\hline \multirow[t]{7}{*}{ CSD } & $\mathrm{X}_{13}$ & 0.969 & 0.654 & 3.54 & 1.22 \\
\hline & $\mathrm{X}_{14}$ & 0.966 & 0.834 & 3.29 & 1.31 \\
\hline & $\mathrm{X}_{15}$ & 0.974 & 0.750 & 3.95 & 1.25 \\
\hline & $X_{16}$ & 0.992 & 0.697 & 3.87 & 1.16 \\
\hline & $X_{17}$ & 0.869 & 0.765 & 4.22 & 1.63 \\
\hline & $\mathrm{X}_{18}$ & 0.920 & 0.857 & 4.37 & 1.54 \\
\hline & $X_{19}$ & 0.859 & 0.742 & 4.48 & 1.69 \\
\hline \multirow[t]{3}{*}{$\mathrm{CL}$} & $x_{20}$ & 0.917 & 0.958 & 3.59 & 1.93 \\
\hline & $x_{21}$ & 0.501 & 0.632 & 3.57 & 2.21 \\
\hline & $x_{22}$ & 0.885 & 0.941 & 3.13 & 2.14 \\
\hline
\end{tabular}

$\mathrm{CL}$, customer loyalty; CSD, customer satisfaction/delight; PESDs, perceived employee service delivery skills; PV, perceived value; TRST, trust.

TABLE 4: Average variance extracted, squared interconstruct correlations and composite trait reliability.

\begin{tabular}{lccccc}
\hline Variable & PESDs & TRST & PV & CSD & CL \\
\hline PESDs & $0.655 \dagger$ & - & - & - & - \\
TRST & 0.349 & $0.637 \dagger$ & - & - & - \\
PV & 0.556 & 0.353 & $0.610 \dagger$ & - & - \\
CSD & 0.470 & 0.243 & 0.464 & $0.968 \dagger$ & - \\
CL & 0.383 & 0.435 & 0.351 & 0.316 & $0.734 \dagger$ \\
Composite trait reliability & 0.710 & 0.796 & 0.782 & 0.986 & 0.842 \\
\hline
\end{tabular}

$\mathrm{CL}$, customer loyalty; CSD, customer satisfaction/delight; PESDs, perceived employee service delivery skills; PV, perceived value; TRST, trust.

$\dagger$, AVE reflected diagonally, and squared correlations below AVE.

\section{Structural model assessment}

After the psychometric properties of the model had been evaluated and subliminal assumptions investigated, it was critical to evaluate the structural properties of the model. For the measurement model, goodness-of-fit measures were evaluated, and the goodness-of-fit metrics are within the limits as prescribed by Hair et al. (2014), except for the normed chi-square $\left(c^{2} / d f\right)$, which slightly exceeds the value of 3. The goodness-of-fit metrics are all above the threshold of 0.9 and the RMSEA is below a value of 0.08 , as indicated by Table 5 .

With respect to the hypothesised relationships postulated for the study, it was found that the hypotheses were supported (Table 6). Considering these findings, validity is secured.

\section{Discussion}

The study investigated the satisfaction/delight experiences of cellular network customers in Botswana and how such experiences influence their loyalty towards their cell phone network service provider. The findings of this study are supported by the SEM conducted to establish the relationship between satisfaction/delight, its antecedents and outcome in a cellular network environment. The SEM analysis indicates a significant relationship between the perceived service delivery skills of cellular network employees and the satisfaction/delight experience of customers. This implies that in the context of Botswana as an emerging African market, cellular network customers want their cell phone network service providers to be honest when engaging with them, treat them with respect, understand their individual needs and listen to them when they are engaged in communication. The majority of respondents indicated that respect and honesty are two foundations of service quality without which satisfaction in the service experience cannot be secured. This corresponds with a study by Wang, Luo and Tai (2017), indicating that employee-customer engagement in the service delivery process should be founded on service quality that is guided by emotional connectivity, respect, integrity and friendliness.

In addition, it was established that a significant relationship exists between PV and CSD. This implies that cellular network customers utilise the cellular service provider because it offers value for money. They are of the opinion that prices charged for services delivered are positively aligned with the overall level of service quality offered, and that they will continue to do business with their cellular provider when considering price and service quality. Cellular customers are therefore highly committed to their cellular provider because they believe that the latter is honest

TABLE 5: Measures for goodness-of-fit (structural model).

\begin{tabular}{lcccccccccc}
\hline CMIN & $d f$ & $p$ & CMIN/df & NFI & RFI & IFI & TLI & CFI & RMSEA \\
\hline 345.33 & 125 & 0.00 & 2.762 & 0.98 & 0.91 & 0.96 & 0.97 & 0.94 & 0.042 \\
\hline
\end{tabular}

RMSEA, root mean square error of approximation; $d f$, degree of freedom. 
when engaging with them, treats them with the required respect when doing business and understands their needs. This is especially important because customers also believe that cellular providers do research for their needs and wants when developing new products and services. This makes customers feel part of the cellular brand in the sense that products and services are developed together with them, rather than for them, thereby stimulating customer trust in the cellular network. Torres and Kline (2013) agree, stating that through continuous customer research an organisation will be better equipped to understand how to design product and service strategies that are founded on customer expectations.

Finally, it can be concluded that cellular customers in Botswana are not simply satisfied with the service that they receive from their cellular network, but are delighted. Respondents indicated that the service of the cell phone network service provider greatly exceeds their expectations and that the value they receive from the services is extremely high. This positive confirmation is further supported by the perception of cellular customers in Botswana that cellular network service provider employees are highly proficient and that the service they deliver is of such a high standard that it will be remembered for a long time. Especially the post-purchase customer support provided by cellular network providers is memorable because of its high quality and professional nature, ultimately leading to extensive service recovery and positive word-of-mouth. Such a positive service experience therefore ultimately results in positive word-of-mouth and customer retention, leading to loyalty towards the cellular provider in the long term. Table 6 reflects on the different hypotheses supported in the study.

\section{Theoretical and managerial implications}

The findings of the study reflect that PESD, PV, and trust have a significant positive influence on the satisfaction/ delight experiences of customers, while such experiences influence CL in a positive and significant manner. Previous research studies (Berman, 2005; Lee \& Park, 2019; Wang et al., 2017) validate that enhanced level of customer satisfaction ultimately leads to greater customer delight outcomes. However, this will depend on the service provider's ability to meet the employee service delivery skills, PV and trust expectations of customers (Dinh \& Pickler, 2012; Lam, Lau, \& Cheung, 2016; Ludwig, Barnes, \& Gouthier, 2015; Makanyezaa, Macheyo, \& Du Toit, 2016; Morgan \& Hunt, 1994; Pansari \& Kumar, 2017; Razzaque \& Boon, 2003; Trasorras, Weinstein, \& Abratt, 2009). The following theoretical implications flow from the study.

TABLE 6: Summary of findings.

\begin{tabular}{llll}
\hline H1 & H2 & H3 & H4 \\
\hline PESDs/CSD & PV/CSD & TRST/CSD & CSD/CL \\
Supported & Supported & Supported & Supported \\
\hline
\end{tabular}

$\mathrm{CL}$, customer loyalty; CSD, customer satisfaction/delight; $\mathrm{PESD}$, perceived employee service delivery skills; PV, perceived value; TRST, trust; $\mathrm{H}$, hypothesis.

\section{Theoretical implications}

Greater clarification on the contribution of relationship marketing in fostering loyalty through customer delight

In the theoretical theory grounding discussion of this article, the importance of developing long-term relationships with customers through a relational approach was postulated. Scholars have also posited the importance of customer satisfaction as a precursor to securing CL in B2C relationship building for more than three decades (Chang et al., 2009; Chiou \& Droge, 2006; Kim et al., 2015; Leninkumar, 2017). However, increasingly, scholars have argued the underlying driver of CL to be the phenomenon of delight (Ball \& Barnes, 2017; Lee \& Park, 2019; Torres, 2013). The current research findings consequently make a valuable contribution in this regard by emphasising the role of delight in the establishment of loyalty in B2C relationships. Specifically, the results prove that the process may be explained from an RMT perspective because the loyalty of the customer is not only built on his or her happiness and joy, but also with the intention to build a long-term relationship when delighted. To the authors' knowledge, the building of loyalty from an RMT perspective has not been formally explored before. It has only previously been found that customers, who are delighted, might have a positive behavioural intention or the potential for loyalty. However, such an outcome does not reflect a strong intent to build a long-term relationship with the provider that is founded on RMT-guided principles (Barnes et al., 2016; Berman, 2005; Torres et al., 2018). The current research findings endorse the contribution of RMT in ensuring that the building of long-term relationships with customers is built on delight which may ultimately foster CL behaviour. Future studies could build on the results of this study to further develop RMT as an important research theory in the relationship marketing domain that may ultimately influence CL behaviour.

\section{Improved understanding of the antecedents of satisfaction/delight}

The findings reflected by this study provide insight into the precursors of CSD within a relationship marketing context. The interrelationship between PESD, PV and trust (as precursors) and CSD has been validated. Fundamentally, knowledge of this distinctive set of factors is important and has significant implications for marketing theory. It seems that customers' satisfaction/delight experiences is not always founded on a single factor, but rather a combination of factors that collectively influence the overall satisfaction/delight experience of customers. It is also plausible that customers want to experience a service as interactive, reliable, situationspecific and culturally sensitive. Existing marketing research on satisfaction/delight predominantly favoured studies exploring customers approval, joy or happiness of the service received (Bowden-Everson et al., 2013; Ma, Scott, Gao, \& Ding, 2017; Preko et al., 2014) and the results of this study consequently provide a different view on the matter. The results of this study argue for a more holistic focus on the antecedents of satisfaction/delight, understanding the 
combined influence of these antecedents on satisfaction/ delight, rather than their individual influence as potential precursors. Considering this, it may be required of marketing theory to further explore the satisfaction/delight experiences of customers in different service settings or the combined influence of a different set of satisfaction/delight precursors from the perspective of various customer segments in emerging markets.

\section{A perspective on the satisfaction/delight link to loyalty}

The research results of this study do provide validation of the previously established relationships between satisfaction/delight and loyalty. Similar to the work of Liu and Keh (2015) and Chitturi, Raghunathan and Mahajan (2008), this study established a positive and significant relationship between the satisfaction/delight experiences of customers and their loyalty towards the service provider. As a result, it would seem that the satisfaction/ delight experiences of customers also lead to their loyalty towards the provider in an emerging market and should therefore be included in future services marketing studies on $\mathrm{CL}$ in these markets. Another inference of this finding is that validation is also postulated on the growing importance of delight as a relational factor that influences loyalty in the long-term. Therefore, when customers evaluate the service performance of a provider, they are increasingly focusing on the uniqueness of the service offering, the value received, and the speed and professionalism of the service recovery process. Customers may adopt a loyalty approach towards the service provider when they perceive the service process to be a pleasurable experience that is characterised by competence, efficiency and delight. As such, the underlying delight expectations of customers in an emerging market such as South Africa may be somewhat different from the delight expectations of customers in more established markets of the world. Marketing theory needs to reflect on the changing delight needs of customers across market types to understand customer segments better.

\section{Managerial implications}

The results of the study clearly underwrite the importance of customer delight as a differentiator for cellular service providers in an emerging African market. These suppliers should strengthen positive experiences founded on service excellence, trust, product knowledge, empathy and understanding that can enhance the overall satisfaction experience of the customer, ultimately leading to delight. Such an experience can strengthen the overall commitment of the customer, leading to a strong loyalty intention in the long term. The overall service experience should therefore be characterised by empathy, understanding, friendliness and joy, leading to a positive engagement with the customer, thereby enhancing trust in the brand and the overall value provision of the cellular provider. This finding is aligned to the findings of the studies by Wang et al. (2017), Ball and Barnes (2017) and Oliver, Rust and Varki (1997), arguing that in a $\mathrm{B} 2 \mathrm{C}$ environment, customers desire a positive experience that is founded on professional service delivery, positive engagement, problem-solving and excellent after-sales support. Therefore, customers want products and services that do more than simply satisfy their needs and that provide an unexpected level of value in the long term (Cossío-Silva et al., 2016). Considering this, the service experience of cellular network customers should exceed their expectations in such a manner that their overall experience is a delight. This can ultimately stimulate the loyalty of the customer in the long term.

Secondly, service delivery experiences can be enhanced through an improved understanding of customer segment needs and the customer value expectations within a specific service setting. Service delivery should be founded on a single customer engagement basis characterised by professionalism. Such professionalism can include an understanding of customers' desire to engage with the provider in a friendly, supportive and engaging manner. In addition, customers want to feel that during a service interaction their presence is acknowledged, their communication is noted, their complaints are immediately addressed and resolved, and their time spent engaging is respected. This finding is aligned to the findings of a study by Schneider and Bowen (1999) more than two decades ago, illustrating that also in emerging markets, the desire of customers to be acknowledged and addressed is strong and critical in building long-term relationships. Considering this, employees should be continuously trained on issues such as communication skills, conflict resolution skills, product knowledge and emotional intelligence to enhance the service experience of the customer both during and after the service engagement. This would ensure that the customer experiences a delightful service engagement that is founded on positive communication and a caring attitude towards the customer. In addition, the customer's perception of the value of the cellular company's offering would be determined by aspects such as the rates charged, the prices and costs of conducting business with the company, and eventually, the service quality level provided. This study illustrates that not only professionalism in the service delivery process is critical in developing delight, but also securing an in-depth understanding of the individual segment needs of the target market to whom the service delivery is secured. This proposition is aligned to the outcome of studies by Torres et al. (2018) and Berman (2005), clearly stating that the expectations of consumer segments are endlessly changing because of competition as well as their own experiences. A service provider should therefore understand that different market segments can have different expectations towards a provider in terms of their delight prospects.

Thirdly, customer delight should be secured by ensuring that the customer trusts the cellular brand more through the service engagement experience. Trust in the service brand could be enhanced by ensuring that employees respect the customer and his or her time more when engagement is secured, that the cellular provider is reliable in its service 
promises, that the overall level of service quality delivered is consistently high, and that the cellular provider and its employees are truthful and honest in their communication and engagement with the customer during and after a service experience. Therefore, delivery on all obligations towards customers should be timeously secured without any excuses made for non-delivery or non-compliance, and promises to deliver a product or service at a specific time should be fulfilled as customers have been led to expect. This finding is well aligned to the study by Bowden-Everson et al. (2013), illustrating that consumer expectations towards trust in a B2C environment are similar in both emerging and established market environments. It is therefore plausible to argue that the nature of consumers, as individual human beings, reflects a universal desire to trust, but that such trust must be earned.

In conclusion, cellular providers in emerging economies in Africa should be trustworthy and transparent in their business transactions with customers, who should be valued and respected and their preferences understood through continuous research. Customers will have a stronger loyalty inclination when cellular providers have empathy for their needs and expectations, when service quality levels are high, irrespective of the time of day, and when problems are resolved in a fast and efficient manner by friendly employees who secure a positive engagement experience. Through such an approach, a cellular provider will become more successful in ensuring a delightful experience for the customer, thereby developing strong relationships that ensure the loyalty of the customer in the long term. Customers no longer want just to be satisfied; they want to be delighted. Such delight can be delivered when the cellular provider manages its customers as partners, when it is willing to receive customer ideas and negative feedback with an open mind, and when there is open and truthful engagement with customers to nurture long-term relationships with them. As a result, the positive influence of customer delight on the loyalty of consumers can secure a service provider with a competitive advantage (Roberts-Lombard \& Petzer, 2018).

\section{Conclusion}

The study established that the satisfaction/delight experiences of cellular customers are influenced by the employee service delivery skills provided. Considering this, the findings of the study provide clarity on the antecedents that influence the CSD experiences of cellular customers in the African market context. The study also guides cellular providers on the important factors to consider when building long-term relationships with customers by securing customer delight experiences.

A limitation of the study is that three antecedents, including the service experience, value perceptions and trust perspectives of customers, were measured in only one service environment. However, the study provides guidance on which precursors influence the satisfaction/ delight experiences of cellular network service provider customers in Botswana, and how CSD influences CL. This knowledge can help cellular companies in Botswana and other emerging African markets to prioritise the development of CSD experiences, which can be beneficial to the companies and to their customers.

\section{Acknowledgements Competing interests}

The authors declare that no competing interest exists.

\section{Authors' contributions}

All authors contributed equally to this work.

\section{Ethical consideration}

This article followed all ethical standards for carrying out research. Approval received from the Ministry of Tertiary Education, Research, Science and Technology (MOTE 1/18/6 VII [19]).

\section{Funding information}

This research received no specific grant from any funding agency in the public, commercial or not-for-profit sectors.

\section{Data availability statement}

Data were analysed using SPSS Amos version 23 (2015). The data that support the findings of this study are available upon reasonable request.

\section{Disclaimer}

The views and opinions expressed in this article are those of the authors and do not necessarily reflect the official policy or position of any affiliated agency of the authors.

\section{References}

Ajzen, I., \& Fishbein, M. (1980). Understanding attitudes and predicting social behaviour. Englewood Cliffs, NJ: Prentice-Hall.

Arnold, M.J., Reynolds, K.E., Ponder, N., \& Lueg, J.E. (2005). Customer delight in a retail context: Investigating delightful and terrible shopping experiences. Journal of Business Research, 58(8), 1132-1145.

Ball, J., \& Barnes, D.C. (2017). Delight and the grateful customer: Beyond joy and surprise. Journal of Service Theory and Practice, 27(1), 250-269. https://doi. org/10.1108/JSTP-01-2016-0013

Barnes, D.C., Beauchamp, M.B., \& Webster, C. (2010). To delight, or not to delight? This is the question service firms must address. Journal of Marketing Theory \& Practice, 18(3), 295-303. https://doi.org/10.2753/MTP1069-6679180305

Barnes, D.C., Collier, J.E., Howe, V., \& Hoffman, K.D. (2016). Multiple paths to customer delight: The impact of effort, expertise and tangibles on joy and surprise. Journal of Services Marketing, 30(3), 277-289. https://doi.org/10.1108/JSM-05-20150172

Berman, B. (2005). How to delight your customers. California Management Review, 48(1), 129-151. https://doi.org/10.2307/41166331

BOCRA. (2018). Annual report. Retrieved from https://www.bocra.org.bw/bocraannual-report-2018

BOCRA. (2019). Telecom statistics. Retrieved from https://www.bocra.org.bw/ telecoms-statistics

Bolton, R.N., Parasuraman, A., Hoefnagels, A., Migchels, N., Kabadayi, S., Gruber, T., \& Solnet, D. (2013). Understanding generation $Y$ and their use of social media: A review and research agenda. Journal of Service Management, 24(3), 245-267. https://doi.org/10.1108/09564231311326987 
Bowden-Everson, J.L., Dagger, T.S., \& Elliot, G. (2013). Engaging customers for loyalty in the restaurant industry: The role of satisfaction, trust and delight. Journal of Foodservice Business Research, 16(2), 52-75. https://doi.org/10.1080/15378020. Foodservice Busi

Bowen, J.T., \& McCain, S-L., C. (2015). Transitioning loyalty programs: A commentary on the relationship between customer loyalty and customer satisfaction International Journal of Contemporary Hospitality Management, 27(3), 415-430. https://doi.org/10.1108/IJCHM-07-2014-0368

BuddyComm. (2019). Botswana - Telecoms, mobile and broadband - Statistics and analyses. Botswana's government commits more funds for ITCs in 2019 budget. Retrieved from https://www.budde.com.au/Research/Botswana-TelecomsMobile-and-Broadband-Statistics-and-Analyses

Bush, J., \& Hair, J.F. (1985). An assessment of the mall intercept as a data collection method. Journal of Marketing Research, 22(2), 158-167. https://doi. org/10.1177/002224378502200205

Chang, H.H., Wang, Y.H., \& Yang, W.Y. (2009). The impact of e-service quality, custome satisfaction and loyalty on e-marketing: Moderating effect of perceived value. Total Quality Management \& Business Excellence, 20(4), 423-443. https://doi org/10.1080/14783360902781923

Chang, K.C. (2014). Examining the effect of tour guide performance, tourist trust, tourist satisfaction, and flow experience on tourists' shopping behavior. Asia Pacific Journal of Tourism Research, 19(2), 219-247. https://doi.org/10.1080/109 41665.2012.739189

Chiou, J.S., \& Droge, C. (2006). Service quality, trust, specific asset investment, and expertise: Direct and indirect effects in a satisfaction-loyalty framework. Journa of the Academy of Marketing Science, 34(4), 613-627. https://doi. org/10.1177/0092070306286934

Chitturi, R., Raghunathan, R., \& Mahajan, V. (2008). Delight by design: The role of hedonic versus utilitarian benefits. Journal of Marketing, 72(3), 48-63. https:// doi.org/10.1509/JMKG.72.3.048

Chuah, S. H.-W., Marimuthu, M., Kandampully, J., \& Bilgihan, A. (2017). What drives gen $Y$ loyalty? Understanding the mediated moderating roles of switching costs and alternative attractiveness in the value-satisfaction-loyalty chain. Journal of and alternative attractiveness in the value-satisfaction-loyalty chain. Journal of
Retailing and Consumer Services, 36, 124-136. https://doi.org/10.1016/j. Retailing and Consumer
jretconser.2017.01.010

Consuegra, D., Molina, A., \& Esteban, A. (2007). An integrated model of price, satisfaction and loyalty: An empirical analysis in the service sector. Journal of Product and Brand Management, 16(7), 459-468. https://doi. org/10.1108/10610420710834913

Cossío-Silva, F.-J., Revilla-Camacho, M.-A., Vega-Vázquez, M., \& Palacios-Florencio, B. (2016). Value co-creation and customer loyalty. Journal of Business Research (2016). Value co-creation and customer loyalty. Journal of Bus
$69(5), 1621-1625$. https://doi.org/10.1016/j.jbusres.2015.10.028

Crosby, L.A., Evans, K.R., \& Cowles, D. (1990). Relationship quality in services selling: An interpersonal influence perspective. Journal of Marketing, 54(3), 68-81. https://doi.org/10.1177/002224299005400306

Dabholkar, P.A., \& Sheng, X. (2012). Consumer participation in using online recommendation agents: Effects on satisfaction, trust, and purchase intentions. The Service Industries Journal, 32(9), 1433-1449. https://doi.org/10.1080/02642 069.2011 .624596

Dagger, T.S., \& Sweeney, J.S. (2007). Service quality attribute weights: How do novice and longer-term customers construct service quality and perceptions? Journal of Service Research, 10(1), 22-42. https://doi.org/10.1177/1094670507303010

De Waal, A., \& Van der Heijden, B. (2016). Increasing customer loyalty and customer intimacy by improving the behavior of employees. Journal of Strategy and Management, 9(4), 492-510.

Dickson, C.A.W., McVittie, C., \& Kapilashrami, A. (2017). Expertise in action: Insights into the dynamic nature of expertise in community-based nursing. Journal of Clinicla Nursing, 27(3-4), 451-462. https://doi.org/10.1111/jocn.13950

Dinh, V., \& Pickler, L. (2012). Examining service quality and customer satisfaction in the retail banking sector in Vietnam. Journal of Relationship Marketing, 11(4) 199-214. https://doi.org/10.1080/15332667.2012.741022

Elbeltagi, I., \& Agag, G. (2016). E-retailing ethics and its impact on customer satisfaction and repurchase intention: A cultural and commitment-trust theory perspective. Internet Research, 26(1), 288-310. https://doi.org/10.1108/IntR-102014-0244

Elias-Almeida, A., Miranda, F.J., \& Almeida, P. (2016). Customer delight: Perception of hotel spa consumers. European Journal of Tourism, Hospitality and Recreation 7(1), 13-20. https://doi.org/10.1515/ejthr-2016-0002

Ercis, A., Unal, S., Candan, B., \& Yildirim, H. (2012). The effect of brand satisfaction trust and brand commitment on loyalty and repurchase intentions. ProcediaSocial and Behavioral Sciences, 58, 1395-1404. https://doi.org/10.1016/j. sbspro.2012.09.1124

Galvão, M.B., De Carvalho, R-C., De Oliveira, L.A.B., \& De Medeiros, D.D. (2018) Customer loyalty approach based on CRM for SMEs. Journal of Business \& Industrial Marketing, 33(5), 706-716. https://doi.org/10.1108/JBIM-07-20170166

Gaskin, J. (2013). SEM series part 6: Multivariate assumptions. [Video recording] Retrieved from https://www.youtube.com/watch?v=Gkp1DKbU-es

Gerpott, T.J., Rams, W., \& Schindler, A. (2001). Customer retention, loyalty, and satisfaction in the German mobile cellular telecommunications market Telecommunications Policy, 25(4), 249-269. https://doi.org/10.1016/S03085961(00)00097-5

Giovanis, A., Athanasopoulou, P., \& Tsoukatos, E. (2015). The role of service fairness in the service quality - Relationship quality - Customer loyalty chain - An empirical study. Journal of Service Theory and Practice, 25(6), 744-776. https://doi. org/10.1108/JSTP-11-2013-0263
Grönroos, C. (2017a). Relationship marketing and service: An update. Journal of Global Scholars of Marketing Science, 27(3), 201-208. https://doi.org/10.1080/2 1639159.2017.1318666

Grönroos, C. (2017b). Relationship marketing readiness: Theoretical background and measurement directions. Journal of Services Marketing, 31(3), 218-225. https:// doi.org/10.1108/JSM-02-2017-0056

Gul, R. (2014). The relationship between reputation, customer satisfaction, trust, and oyalty. Journal of Public Administration and Governance, 4(3), 368-387. https:// doi.org/10.5296/jpag.v4i3.6678

Gummesson, E. (2017). From relationship marketing to total relationship marketing and beyond. Journal of Services Marketing, 31(1), 16-19. https://doi.org/10.1108/ JSM-11-2016-0398

Hair, J.F., Black, W.C., Babin, B.J., \& Anderson, R.E. (2014). Multivariate data analysis (7th edn.). Harlow: Pearson.

Hoogstraten, J.O.H., De Haan, W., \& Ter Horst, G. (1985). Stimulating the demand for dental care: An application for Ajzen's and Fishbein's theory of reasoned action. European Journal of Social Psychology, 15(4), 401-414. https://doi.org/10.1002/ ejsp.2420150404

Izogo, E.E. (2016). Structural equation test of relationship quality repurchase intention - Willingness to recommend framework in retail banking. International Journal of Emerging Markets, 11(3), 374-394. https://doi.org/10.1108/IJOEM-07-2015-0130

Jiang, L., Jun, M., \& Yang, Z. (2016). Customer-perceived value and loyalty: How do key service quality dimensions matter in the context of B2C e-commerce? Service Business, 10(2), 301-317. https://doi.org/10.1007/s11628-015-0269-y

Jiang, Y., Ramkissoon, H., \& Mavondo, F. (2016). Destination marketing and visitor experiences: The development of a conceptual framework. Journal of Hospitality Marketing \& Management, 25(6), 653-675.

Jin, N., Lee, S., \& Lee, H. (2015). The effect of experience quality on perceived value, satisfaction, image and behavioral intention of water park patrons: New versus repeat visitors. International Journal of Tourism Research, 17(1), 82-95. https:// doi.org/10.1002/jtr.1968

Jöreskog, K.G., \& Sörbom, D. (1993). LISREL 8: Structural equation modeling with the SIMPLIS command language. Chicago, IL: Scientific Software International.

Kao, C.Y., Tsaur, S.H., \& Wu, T.C.E. (2016). Organizational culture on customer delight in the hospitality industry. International Journal of Hospitality Management, 56 98-108. https://doi.org/10.1016/j.ijhm.2016.05.001

Kim, M., Vogt, C.A., \& Knutson, B.J. (2015). Relationships among customer satisfaction, delight, and loyalty in the hospitality industry. Journal of Hospitality \& Tourism Research, 39(2), 170-197. https://doi.org/10.1177/1096348012471376

Kotler, P., \& Keller, K.L. (2016). Marketing management (15th edn.). Harlow: Pearson.

Krystallis, A., \& Chrysochou, P. (2014). The effects of service brand dimensions on brand loyalty. Journal of Retailing and Consumer Services, 21(2), 139-147. https:// doi.org/10.1016/j.jretconser.2013.07.009

Kuhn, S., \& Mostert, P. (2018). Relationship intention and relationship quality as predictors of clothing retail customers' loyalty. The International Review of Retail, Distribution and Consumer Research, 28(2), 206-230. https://doi.org/10.1080/09 593969.2017.1380067

Lam, A.Y.C., Lau, M.M., \& Cheung, R. (2016). Modelling the relationship among green perceived value, green trust, satisfaction, and repurchase intention of gree products. Contemporary Management Research, 12(1), 47-60. https://doi. org/10.7903/cmr.13842

Lee, B.Y., \& Park, S.Y., (2019). The role of customer delight and customer equity for loyalty in upscale hotels. Journal of Hospitality and Tourism Management, 39 175-184. https://doi.org/10.1016/j.jhtm.2019.04.003

Leninkumar, V. (2017). The relationship between customer satisfaction and customer trust on customer loyalty. International Journal of Academic Research in Busines and Social Sciences, 7(4), 1-16. https://doi.org/10.6007/JJARBSS/v7-i4/2821

Leroi-Werelds, S., Streukens, S., Brady, M.K., \& Swinnen, G. (2014). Assessing the value of commonly used methods for measuring customer value: A multi-setting empirical study. Journal of the Academy of Marketing Science, 42(4), 430-451. https://doi.org/10.1007/s11747-013-0363-4

Leverin, A., \& Liljander, V. (2006). Does relationship marketing improve customer relationship satisfaction and loyalty? International Journal of Bank Marketing 24(4), 232-251. https://doi.org/10.1108/02652320610671333

Liu, M.W., \& Keh, H.T. (2015). Consumer delight and outrage: Scale development and validation. Journal of Service Theory and Practice, 25(6), 680-699. https://doi. org/10.1108/JSTP-08-2014-0178

Loke, S.P., Taiwo, A.A., Salim, H.A., \& Downe, A.G. (2011). Service quality and customer satisfaction in a telecommunication service provider. International Proceedings of Economics Development and Research (IPEDR), 11, 24-29.

Ludwig, N.L., Barnes, D.C., \& Gouthier, M. (2015). Observing delightful experiences of other customers: The double-edged Sword of jealousy and joy. Journal of Services Theory and Practice, 22(1), 145-163. https://doi.org/10.1108/JSTP-07-2015-0171

Ma, J., Scott, N., Gao, J., \& Ding, P. (2017). Delighted or satisfied? Positive emotional responses derived from theme park experiences. Journal of Travel \& Tourism Marketing, 34(1), 1-19, https://doi.org/10.1080/10548408.2015.1125824

Makanyezaa, C., Macheyo, R., \& Du Toit, F. (2016). Perceived product necessity, perceived value, customer satisfaction and affective attitude: An integrative model. Journal of African Business, 17(1), 69-86. https://doi.org/10.1080/152289 16.2016.1112709

Maria Correia Loureiro, S.J., Miranda, F. \& Breazeale, M. (2014). Who needs delight? The greater impact of value, trust and satisfaction in utilitarian frequent-use retail. Journal of Service Management, 25(1), 101-124. https://doi.org/10.1108/ JOSM-06-2012-0106 
Melewar, T.C., Foroudi, P., Gupta, S., Kitchen, P., \& Foroudi, M.M. (2017). Integrating identity, strategy and communications for trust, loyalty and commitment European Journal of Marketing, 51(3), 572-604. https://doi.org/10.1108/EJM-08European Jour

Meyer, T., Barnes, D.C., \& Friend, S.B. (2017). The role of delight in driving repurchase intentions. Journal of Personal Selling \& Sales Management, 37(1), 61-71. https:// doi.org/10.1080/08853134.2016.1272052

Moghavvemi, S., Lee, S.T., \& Lee, S.P. (2018). Perceived overall service quality and customer satisfaction: A comparative analysis between local and foreign banks in Malaysia. International Journal of Bank Marketing, 36(5), 908-930. https://doi. org/10.1108/IJBM-06-2017-0114

Morgan, R., \& Hunt, S. (1994). The commitment-trust theory of relationship marketing. Journal of Marketing, 58(3), 20-38. https://doi. org/10.1177/002224299405800302

Nyadzayo, M. (2010). The mediating role of customer relationship management on customer retention at selected motor vehicle dealership in the Buffalo City

Nyadzayo, M.W., \& Khajehzadeh, S. (2016). The antecedents of customer loyalty: A moderated mediation model of customer relationship management quality and brand image. Journal of Retailing and Consumer Services, 30(C), 262-270. https:// doi.org/10.1016/j.jretconser.2016.02.002

Ofori, K.S., Boakye, K., \& Narteh, B. (2018). Factors influencing consumer loyalty towards $3 \mathrm{G}$ mobile data service providers: Evidence from Ghana. Total Quality Management \& Business Excellence, 29(5-6), 580-598. https://doi.org/10.1080/ 14783363.2016.1219654

Oliver, R.L., Rust, R.T., \& Varki, S. (1997). Customer delight: Foundations, findings and managerial insight. Journal of Retailing, 73(3), 311-336. https://doi.org/10.1016/ S0022-4359(97)90021-X

O'Malley, L., \& Tynan, C. (2000). Relationship marketing in consumer markets: Rhetoric or reality? European Journal of Marketing, 34(7), 797-815. https://doi. org/10.1108/03090560010331225

Pansari, A., \& Kumar, V. (2017). Customer engagement: The construct, antecedents, and consequences. Journal of the Academy of Marketing Science, 45(3), 294-311. https://doi.org/10.1007/s11747-016-0485-6

Park, E., Kim, K.J., \& Kwon, S.J. (2017). Corporate social responsibility as a determinant of consumer loyalty: An examination of ethical standard, satisfaction, and trust. Journal of Business Research, 76, 8-13. https://doi.org/10.1016/j.jbusres.2017. 02.017

Petrick, J.F. (2004). First timers' and repeaters' perceived value. Journal of Travel Research, 43(1), 29-38. https://doi.org/10.1177/0047287504265509

Preko, A., Agbanu, S.K., \& Feglo, M. (2014). Service delivery, customer satisfaction and customer delight in the real estate business. Evidence from elite kingdom investment and consulting company Ghana. European Journal of Business and Management, 6(3), 71-83.

Ravald, A., \& Grönroos, C. (1996). The value concept and relationship marketing. European Journal of Marketing, 30(2), 19-30. https://doi.org/10.1108/ 03090569610106626

Razzaque, M.A., \& Boon, T.G. (2003). Effects of dependence and trust on channel satisfaction, commitment and cooperation. Journal of Business-to-Business Marketing, 10(4), 23-45. https://doi.org/10.1300/J033v10n04_02

Roberts-Lombard, M., \& Petzer D.J. (2018). Customer satisfaction/delight and behavioural intentions of cell phone network customers - An emerging marke perspective. Europed

Ronzoni, G., \& Torres, E.N. (2018). The evolution of the customer delight construct: Prior research, current measurement, and directions for future research. International Journal of Contemporary Hospitality Management, 30(1), 57-75. https://doi.org/10.1108/IJCHM-09-2016-0528

Rousseau, D.M., Sitkin, J.B., Burt, R.S., \& Camerer, C. (1998). Not so different after all: A cross-discipline view of trust. Academy of Management Review, 23(3), 393-404. https://doi.org/10.5465/amr.1998.926617

Saeed, K., \& Siddiqui, K.A. (2016). Influence of customer's loyalty-satisfaction link on services usage. Journal of Marketing Management and Consumer Behavior, 1(2) 22-31. https://doi.org/10.2139/ssrn.2787391
Saunders, M., \& Lewis, P. (2012). Doing research in business and management. Edinburgh Gate: Pearson.

Schneider, B., \& Bowen, D.E. (1999). Understanding customer delight and outrage. Sloan Management Review, 41(1), 35-45.

Soares, R.R., \& Proença, J.F. (2015). Does service failure context matter? Customers' response to service recovery. Journal of Marketing Research and Case Studies, 2015, 1-11. https://doi.org/10.5171/2015.709531

SPSS Amosversion 23 [computer software]. 2015. Armonk, NY: IBM.

Subhashini, S., \& Preetha, S. (2018). An empirical analysis of service quality factors pertaining to ocean freight forwarding services. Maritime Business Review, 3(3), 276-289. https://doi.org/10.1108/MABR-01-2018-0004

Telegraph. (2015, February 15). Botswana's mobile penetration to hit record high Study. Retrieved from http://www.sundaystandard.info/botswana\%E2\%80\%99smobile-penetration-hit-record-high-study

Torres, E.N., Fu, X., \& Lehto, X. (2014). Are there gender differences in what drives customer delight? Tourism Review, 69(4), 297-309. https://doi.org/10.1108/TR04-2014-0012

Torres, E.N., \& Kline, S. (2013). From customer satisfaction to customer delight: Creating a new standard of service for the hotel industry. International Journal of Contemporary Hospitality Management, 25(5), 642-659. https://doi. Contemporary Hospitality Manager
org/10.1108/IJCHM-Dec-2011-0228

Torres, E.N. Milman, A., \& Park, S. (2018). Delighted or outraged? Uncovering key drivers of exceedingly positive and negative theme park guest experiences. Journal of Hospitality and Tourism Insights, 1(1), 65-85. https://doi.org/10.1108/ JHTI-10-2017-0011

Trasorras, R., Weinstein, A., \& Abratt, R. (2009). Value, satisfaction, loyalty and retention in professional services. Marketing Intelligence and Planning, 27(5), 615-632. https://doi.org/10.1108/02634500910977854

Van Vuuren, T. (2011). Customer loyalty in an optometric practice - A case study perspective (Unpublished MCom dissertation), University of Johannesburg.

Verma, V., Sharma, D., \& Sheth, J. (2016). Does relationship marketing matter in online retailing? A meta-analytic approach. Journal of the Academy of Marketing Science, 44(2), 206-217. https://doi.org/10.1007/s11747-015-0429-6

Wang, Y.C., Luo, C.C., \& Tai, Y.F. (2017). Implementation of delightful services: From the perspective of frontline service employees. Journal of Hospitality and Tourism Management, 31, 90-104. https://doi.org/10.1016/j.jhtm.2016.10.006

Wong, A., \& Zhou, L. (2006). Determinants and outcomes of relationship quality: A conceptual model and empirical investigation. Journal of International Consumer Marketing, 18(3), 81-96. https://doi.org/10.1300/J046v18n03_05

Xu, C., Peak, D., \& Prybutok, V. (2015). A customer value, satisfaction, and loyalty perspective of mobile application recommendations. Decision Support Systems, 79(C), 171-183. https://doi.org/10.1016/j.dss.2015.08.008

Yoon, S., \& Kim, J. (2000). An empirical validation of a loyalty model based on expectation disconfirmation. Journal of Consumer Marketing, 17(2), 120-136. https://doi.org/10.1108/07363760010317196

Zafar, M., Zafar, S., Asif, A., Hunjra, A.I., \& Ahmad, H.M. (2012). Service quality, customer satisfaction and loyalty: An empirical analysis of banking sector in Pakistan. Information Management and Business Review, 4(3), 159-167. https:// doi.org/10.22610/imbr.v4i4.977

Zikmund, W.G. (2000). Exploring Market Research (7th edn.), The Dreyden Press, Fort Worth.

Zhang, J.Z., Watson IV, G.F., Palmatier, R.W., \& Dant, R.P. (2016). Dynamic relationship marketing. Journal of Marketing, 80(5), 53-75. https://doi.org/10.1509/ jm.15.0066

Zhang, M., Huang, L., He, Z., \& Wang, A.G. (2015). E-service quality perceptions: An empirical analysis of the Chinese e-retailing industry. Total Quality Management \& Business Excellence, 26(11-12), 1357-1372. https://doi.org/10.1080/14783363. 2014.933555 